\title{
Development of the prospective specialists' professional responsibility
}

\author{
Potapiuk L.* \\ Lutsk national technical university, Lutsk, Ukraine
}

Received: $09.08 .2020 \quad$ Accepted: 25.09 .2020

\begin{abstract}
Increasing the level of the prospective specialists' professional responsibility is an important aspect of preparing young people for life and work in a highly-competitive and dynamic society. Professional training of the competitive professionals is inextricably interwoven with the development of their abilities, worldview, cognitive independence, moral and ethical culture, national consciousness, ability to perform tasks at a high professional level, solve life and personal problems. With reference to the scientific sources, the article describes varied approaches to the definition of the concept of responsibility. In the focus of the study are the most essential issues of the notion of future specialist's professional responsibility. The author argues that professional responsibility reflects the objectively necessary relationships in a team, which are characterized by a conscious need to fulfill professional requirements, moral and professional duties, social norms, to be responsible for the professional actions as to the colleagues, team, and society. The article highlights the most important areas of vocational education improvement, focusing on the most favorable conditions for the professional responsibility formation, describes the set of factors, requirements, and influences aimed at facilitating the process. Pedagogical conditions involve the factors and professional interests, which contribute to the future specialist's self-sufficiency and self-criticism development, provide for the disclosure of the personality potential, influence the formation of professionally significant qualities of future specialists, improve the quality of their training and inspire the specialist for further development, transformation, and integration into the European and world community. The study has revealed that the mechanisms of professional responsibility formation work more efficiently owing to the implementation of properly selected pedagogical approaches in the process of training. The main components that determine the level of professional responsibility are identified. The key findings of the study argue that the quality of the formation process of the professional responsibility of the prospective specialist depends greatly on the gradual and manageable training, filling the training content with integrative combination of personal, pedagogical and professional components, development of the organizational principles based on the combination of theory and practice, involving students in various types of activity.
\end{abstract}

Key words: responsibility, professional responsibility, professional activity, pedagogical conditions.

\section{Формування профресійної відповідальності майбутніх фахівців}

\author{
Потапюк Л. М.
}

Луцький національний технічний університет, Луцьк, Україна

\begin{abstract}
Анотація. Підготовка молоді до життя та діяльності в конкурентному й динамічному суспільстві потребує підвищення рівня професійної відповідальності майбутніх фрахівців. Якість професійної підготовки конкурентоспроможних фрахівців взаємопов'язана з розвитком їхніх здібностей, формуванням сучасного світогляду, пізнавальної самостійності, морально-етичної культури, національної свідомості, здатності самостійно на високому професійному рівні виконувати поставлені завдання, розв'язувати життєві та особистісні проблеми. На основі аналізу наукових джерел схарактеризовані підходи до дефініції «відповідальність», проаналізовано та розкрито сутність поняття «професійна відповідальність майбутніх фахівців». Обірунтовано, що професійна відповідальність є результатом відображення об'єктивно необхідних взаємин у колективі, які характеризуються усвідомленою особистістю необхідністю виконувати профресійні вимоги, моральний і професійний обов'язок, соціальні норми та відповідати за свої профресійні дії перед собою, колегами, колективом і суспільством. Виділені найважливіші напрями розвитку освіти - умови формування профресійної відповідальності, сукупність обставин, фактори, вимоги, впливи. Встановлено, що педагогічні умови грунтуються на факторах, професійних інтересах, які спрямовують на самодостатність, самокритичність; розкривають можливості особистості; впливають на формування професійно значущих
\end{abstract}

Corresponding Author: Potapiuk Liliia Mykolaivna. Tel. +38(050) 17-27-719. E-mail: potapiuk_@bigmir.net Lutsk National Technical University, 75, Lvivska str., Lutsk, Volyn Region, Ukraine, 43018.

Biдnовідальний автор: Потапюк Лілія Миколаївна. Тел. +38(050) 17-27-719. E-mail: potapiuk_@bigmir.net Луцький національний технічний університет, вул. Львівська, 75, м. Луцьк, Волинської обл., Україна, 43018. 
якостей майбутніх фахівців, підвищення якості їхньої підготовки та акумулюють на подальший розвиток, трансформацію, інтеграцію в європейське і світове співтовариство. Визначено, що механізми фрормування відповідальності діють завдяки застосуванню у процесі підготовки певних педагогічних підходів. Виокремлені основні елементи, які визначають рівень розвитку професійної відповідальності. Доведено, що процес формування професійної відповідальності майбутнього фахівця стає можливим завдяки поетапності й керованості підготовки; забезпечення інтегративних зв'язків особистісних, педагогічних та фахових складових змісту підготовки; розробці змістово-організаційних засад на основі взаємозв'язку теорії і практики; залучання студентів до різноманітних видів діяльності.

Ключові слова: відповідальність, професійна відповідальність, професійна діяльність, педагогічні умови.

\title{
Формирование профессиональной ответственности будущих специалистов
}

Потапюк Л. М.

\author{
Луцкий национальный технический университет, Луцк, Украина
}

\begin{abstract}
Аннотация. Подготовка молодежи к жизни и деятельности в конкурентном и динамичном обществе требует повышения уровня профессиональной ответственности будущих специалистов. Качество профессиональной подготовки конкурентоспособных специалистов тесно связана с развитием их способностей, формированием современного мировоззрения, познавательной самостоятельности, морально-этической культуры, национального сознания, способности самостоятельно на высоком профессиональном уровне выполнять поставленные задачи, решать жизненные и личностные проблемы. На основе анализа научных источников проанализированы подходы К десиниции «ответственность», раскрыта сущность понятия «профессиональная ответственность будущих специалистов». Обосновано, что профессиональная ответственность является результатом отражения объективно необходимых взаимоотношений в коллективе, которые характеризируются осознанной личностью необходимостью выполнять профессиональные требования, моральный и профессиональный долг, социальные нормы и отвечать за свои профессиональные действия перед собой, коллегами, коллективом и обществом. Выделены важнейшие направления развития образования - условия формирования профессиональной ответственности, совокупность обстоятельств, факторы, требования, воздействия. Установлено, что педагогические условия основываются на факторах, профессиональных интересах, которые направлены на самодостаточность, самокритичность; раскрывают возможности личности; влияют на формирование профессионально значимых качеств будущих специалистов, повышение качества их подготовки и аккумулируют на дальнейшее развитие, трансформацию, интеграцию в европейское и мировое сообщество. Определено, что механизмы формирования ответственности действуют благодаря применению в процессе подготовки определенных педагогических подходов. Выделены основные элементы, которые определяют уровень развития профессиональной ответственности. Доказано, что процесс формирования профессиональной ответственности будущего специалиста становится возможным благодаря поэтапности и управляемости подготовки; обеспечению интеграционных связей личностных, педагогических и профессиональных составляющих содержания подготовки; разработке содержательно-организационных принципов на основе взаимосвязи теории и практики; вовлечению студентов в различные виды деятельности.

Ключевые слова: ответственность, профессиональная ответственность, профессиональная деятельность, педагогические условия.
\end{abstract}

\section{Bcmyn}

Трансформація сучасного освітнього середовища України, соціально-економічні перетворення, які постійно відбуваються у суспільстві, ставлять нові вимоги до професійної підготовки майбутніх фахівців. А отже, враховуючи європейський напрямок реформування вітчизняної вищої освіти та приведення Національних стандартів освіти до міжнародної системи стандартів, одним із актуальніших напрямків дослідження є підвищення рівня професійної відповідальності майбутніх фрахівців. Сучасний випускник повинен мати високий рівень професіоналізму та володіти певними компетентностями, що відображається в умінні розвиватись, відповідально ставитись до власних обов'язків, бажанні постійно самовдосконалюватись, навчатись, самореалізовуватись, критично ставитись до результатів своїх зусиль, використовувати компетентно підібрані методи, прийоми, доводити заплановані дії до кінця зі збереженням рівня якості та своєчасності, бути готовим нести відповідальність за свої дії. Саме ринкова економіка спонукає до активної діяльності кожну людину, що стає єдиним шляхом її виживання, подальшого вдосконалення і актуалізує проблему професійної підготовки молоді. Якість професійної 
підготовки майбутніх фахівців взаємопов'язана з розвитком їхніх здібностей, формуванням сучасного світогляду, пізнавальної самостійності, морально-етичної культури, національної свідомості, здатності самостійно на високому професійному рівні виконувати поставлені завдання, розв'язувати життєві та особистісні проблеми. А отже, проблема формування професійної відповідальності особистості завжди була і нині залишається надзвичайно актуальною.

Meта роботи: проаналізувати особливості формування професійної відповідальності майбутніх фахівців як невід'ємного складника морального виховання.

Аналіз попередніх досліджень: відповідальність як важливу якість особистості розглядають Л. Барановська, К. Муздибаєв, А. Ореховський, К. Пахомова, Н. Промашкова та ін. Успішне становлення майбутнього фахівця, яке $€$ складовою загального розвитку особистості, висвітлюють науковці Н. Волянюк, О. Кокун, О. Конопкін, М. Корольчук, Г. Ложкін, С. Максименко, С. Миронець, М. Савчин, О. Сафрін, В. Татенко, Ю. Швалб та ін.

Окремі соціальні аспекти відповідальності розкривають Л. Архангельський, Ю. Благов, Л. Грицина, М. Губачов, Н. Івашина, Є. Левченко О. Плахотний, М. Притула, О. Слобідський та ін. Адміністративна відповідальність розкрита у працях А. Моти, дисциплінарна відповідальність військовослужбовців - у С. Тюріна, В. Чумака; юридичні аспекти відповідальності військовослужбовців у доробках В. Царенка, М. Поліщука; окремі аспекти формування відповідальності військовослужбовців - у працях А. Афанасьєва, О. Аксьонової, М. Видиша, І. Гамули, М. Нещадима, Ю. Сичевського; правові аспекти відповідальності висвітлюють В. Лук'янов, Г. Васянович, А. Перлін; особливості професійної відповідальності як особистісної якості розглядають І. Бех, А. Вербицький, Ю. Добромиський, В. Зазикін, І. Єрмаков, О. Конопкін, Л. Нерсесян, В. Нєбиліцин, С. Рубінштейн, Х. Хекхаузен та ін.

Психологічний аспект формування відповідальності проаналізований у наукових доробках В. Ковальова, О. Леонтьєва, К. Муздибаєва, В. Мясищева, С. Рубінштейна, М. Савчина, Д. Узнадзе. Дослідженню особливостей формування відповідальності студентів в освітньому процесі закладу вищої освіти присвячені роботи Л. Барановської, Л. Нора, Н. Чернової. У наукових дослідженнях К. Абульханової-Славської, Б. Ананьєва, Л. Анциферової, А. Бодальова, Л. Божович, А. Деркача, А. Крупнова, Н. Рейнвальд, Д. Фельдштейна, І. Куренкова, В. Сахарової розкриті закономірності й механізми процесу особистісного розвитку. Проблеми моральної відповідальності досліджували Т. Василевська, Г. Гаєвая, Ф. Майленова, А. Мітькіна, М. Станчиць, І. Трихін.

Формування професійно значущих особистісних якостей майбутніх фрахівців розглядали О. Абдулліна, В. Арюткін, А. Губайдулліна, Л. Ігнатенко, Н. Кузьміна, М. Махмутов, Ф. Мухаметзянова, Н. Посталюк, Л. Свіріна, В. Сластьонін, А. Спірін, Л. Уманський та ін. Основою педагогічної теорії відповідальності є праці А. Алфььорова, В. Коротова, А. Макаренка, В. Сухомлинського. Дослідженням професійної відповідальності займались Л. Бешевець, С. Букша, О. Мухаметшин, В. Романов, В. Шатенко та інші. Мотиваційне підірунтя відповідальної поведінки особистості досліджували О. Агапонов, В. Асеєв, І. Зайцева, В. Ковальов, Х. Хекхаузен, І. Прокопенко, Е. Павлютенков, О. Макаревич, А. Маркова, Т. Матіс, А. Орлов.

Зарубіжні науковці Ж. Піаже, Л. Колберг, Е. Фром, К. Хелкама проблему відповідальності розглядають у моральному аспекті, а Дж. Агассі, П. Друкер, Д. Зіглер, П. Фейерабенд, Ф. Хайдер, Л. Хьєлл, К. Юнг - в аспекті причинності. Отож, наукові положення, що містяться у зазначених вище та інших наукових працях, мають велику цінність для вирішення завдань нашого дослідження. Однак стрімкий розвиток суспільства диктує все нові вимоги до професійної підготовки майбутніх фахівців, що підтверджує актуальність досліджуваної тематики.

\section{II Матеріал і методи дослідження}

Для реалізації мети, розв'язання поставлених завдань, перевірки гіпотези використано комплекс методів, за допомогою яких була здійснена характеристика досліджуваного френомену і з'ясована сутність поняття «професійна відповідальність». Зокрема, аналіз наукових джерел з проблем ефективності підготовки фахівців у вищій школі, порівняння, узагальнення та систематизація наукових даних, методи аналізу для зіставлення та порівняння поглядів вчених на проблему формування професійної відповідальності, визначення напрямів дослідження та понятійно-категоріального апарату; синтез; логічне узагальнення. 
Як відомо, підготовка молоді до життя та діяльності в конкурентному й динамічному суспільстві потребує спільного особистісного і професійного зростання усіх суб'єктів освітнього процесу. Порушена проблема виявляється органічно пов'язаною і з реальною освітньою практикою та з практичним здійсненням майбутньої професійної діяльності наших випускників. 3 одного боку, розв'язання цієї проблеми має бути спрямоване на більш глибоке визначення цілей і змісту освіти, методики і технології ефективного навчання. 3 іншого боку, варто відновити високий авторитет вітчизняної освіти і знань в суспільній свідомості людства. Так, відповідно до Національної доктрини розвитку освіти України у XXI столітті, Концепції національного виховання та Закону України «Про освіту» визначені посилені вимоги до професійних і особистісних якостей випускників закладів вищої освіти, зосереджена увага на їх підготовці (розвитку професійного потенціалу, формуванні високої професійної відповідальності, загальнокультурного рівня випускників) 3 метою ефективнішого фрункціонування та подальшого входження в європейські, світові економічні структури України. Також проблема підготовки майбутніх фахівців обумовлена у Проекті Стратегії сталого розвитку України на період до 2030 року, яка орієнтована на вектори, визначені в Стратегії сталого розвитку «Україна - 2020». Нова світоглядна парадигма, на якій грунтується Стратегія, є політичною та практичною моделлю такого розвитку всіх країн світу, який задовольняє потреби нинішнього покоління без шкоди для можливості майбутніх поколінь задовольняти свої власні потреби. Ця модель орієнтована на досягнення оптимального балансу між трьома складовими розвитку - економічною, соціальною та екологічною.

Перехід до сталого розвитку - це процес зміни ціннісних орієнтацій багатьох людей. Визнаними міжнародними фундаментальними цінностями розвитку є свобода, рівність, солідарність, толерантність, повага до природи, спільна відповідальність. Національні цілі сталого розвитку базуються на політичних, економічних, соціальних, екологічних, моральних і культурних цінностях, властивих українському суспільству. Вони визначають спрямованість стратегії на турботу про спільне благо та захист національних інтересів України. Освіта $€$ однією з передумов досягнення сталого розвитку і найважливішим інструментом ефективного управління та обґрунтованого прийняття рішень. Університети та інші навчальні заклади повинні забезпечувати підготовку кваліфікованих фахівців 3 необхідними компетентностями для розробки і використання новітніх технологій, які забезпечують перехід суспільства до сталого розвитку. Однією з характеристик освіти для сталого розвитку $є$ їі гуманізація та звернення до духовно-моральних цінностей людства, і на цій основі має будуватися творча, ціннісна, відповідальна діяльність майбутнього фрахівця в процесі навчання у 3ВО [1].

Вивчення наукових доробків вітчизняних й зарубіжних дослідників показало, що вони пов'язують феномен відповідальності із зростанням моральної цілісності особистості, інтегрованості різних проявів моральної поведінки, усвідомленості й готовності виконувати обов'язок, здатністю відчувати і сприймати моральні почуття, безконфліктно вирішувати питання моралі у спілкуванні та міжособистісній взаємодії.

А отже, відповідальність $є$ надзвичайно складним морально-етичним, психічним утворенням та суперечливим явищем. Відповідальність носить індивідуальний і водночас суспільний характер та відіграє важливу роль у забезпеченні нормальної життєдіяльності суспільства і людини у ньому, в реалізації своєї місії й особистісного потенціалу. Передумовою відповідальності завжди $є$ вибір людиною можливої поведінки, що проявляється у власній активності, діяльності та самовдосконаленні.

Відповідальність $є$ базовою моральною цінністю особистості, що визначається наявністю знань про моральні норми та цінності, сфрормованістю уявлень про сутність моральних обов'язків стосовно об'єктів і суб'єктів навколишнього середовища та самого себе, умінням реалізовувати дії у власній діяльності та вчинках без зовнішнього регулювання. Це обов'язок виконувати всі зобов'язання як вираження об'єктивної необхідності і закономірності суспільного життя.

Нести відповідальність означає приймати на себе всі наслідки своїх вчинків. Відповідальній поведінці протистоїть безвідповідальна. Безвідповідальність завжди пов'язана з байдужістю й легковажністю або з надмірною самовпевненістю. Насамперед, безвідповідальність означає спробу перекласти наслідки своїх вчинків на інших.

3 огляду на це, до основних чинників, які системно і цілеспрямовано формують відповідальність людини, відносять навчання, виховання, соціалізацію, особистісний розвиток, життєвий досвід, суспільну практику, сім'ю, систему освіти, релігійні організації, засоби масової інформації, трудові колективи та інші соціальні групи, суспільство, його моральні принципи і переконання, моральні й 
професійні якості фрахівця, правову систему, загальну і професійну культуру. Усі ці чинники взаємопов'язані між собою і вливають на людину у більшій або меншій мірі.

На думку $€$. Мануйлова, відповідальність як внутрішня особливість індивіда - це складне соціальне явище, яке включає усвідомлення необхідності діяти згідно із суспільними вимогами та соціальними цінностями, усвідомлювати свою суспільну роль, критичність і постійний контроль за власними діями, готовність відповідати за свої вчинки та соціально значущу діяльність [14].

У тлумачному словнику психологічних термінів поняття «відповідальність» визначають як здатність особистості розуміти відповідність результатів своїх дій поставленим цілям, прийнятим у суспільстві або в колективі нормам, у результаті чого виникає почуття співучасті в загальній справі, а при невідповідальності - почуття невиконаного обов'язку [5, с. 25].

На рівні психологічного аналізу відповідальність розглядається як загальна властивість особистості, що поєднує компоненти афективно-мотиваційної, інтелектуальної та діяльно-поведінкової сфер людини як тілесно духовної цілісності. Тут відповідальність постає як результат інтеграції усіх психічних функцій особистості: суб'єктивного сприйняття навколишнього світу, оцінки власних чуттєвих ресурсів, емоційного ставлення до обов'язку, волі [17].

А отже, у структурі відповідальності виділяють три взаємопов'язані компоненти: когнітивний, афрективно-мотиваційний і поведінковий (діяльнісний). Так, когнітивний компонент передбачає систему розширення і поглиблення знань про норми і правила відповідальної поведінки, передбачення наслідків особистої діяльності; соціальні знання про шляхи реалізації відповідальності та самооцінку. Мотиваційний компонент передбачає усвідомлене ставлення до обов'язків, постійне прагнення до вдосконалення своєї індивідуальності, позитивне ставлення до моральних норм, бажання діяти відповідно до них. Діяльнісний компонент включає в себе готовність особистості дотримуватися норм та вимог суспільства, відповідати за наслідки своїх вчинків, виконувати соціальні ролі, здатність контролювати і коригувати свою поведінку до норм.

Механізми формування відповідальності майбутніх фахівців діють завдяки застосуванню в процесі підготовки певних педагогічних підходів, а саме:

1. Індивідуального (ґрунтовне вивчення індивідуальних особливостей і діяльності особистості; визначення найбільш конкретних та віддалених цілей розвитку її якостей).

2. Професіографічного (розробка оптимальних професійних патернів - набору стереотипних поведінкових реакцій або послідовностей дій.

3. Підходу за принципом розвитку (урахування поступовості змін стосовно потенційних та актуальних можливостей особистості).

4. Контекстного (включення елементів майбутньої професійної діяльності до навчальновиховного процесу).

5. Культурологічного (розгляд категорії відповідальності як структурного елемента загальної та профресійної культури фахівця).

6. Акмеологічного (орієнтація особистості на прогресивний розвиток і реалізацію в професійній діяльності [ 16, с. 327 ].

Усі зазначені вище підходи щодо формування відповідальності підтверджують ідею про тісну взаємодію індивідуального (спадковість, особливості організму, стан здоров'я, фрізична і психічна енергетика), особистісного (відношення, мотиви, інтелект, емоційно-вольова сфера) і професійного (індивідуальні особливості, особистісні характеристики) розвитку людини. Особливе місце у складній системі особистої відповідальності посідає професійна відповідальність, яка є інтегративною складовою профресійної готовності майбутніх фахівців.

Отже, становлення майбутнього фрахівця передбачає розвиток його як особистості, який відбувається в діяльності. Тому особистість головним чином проявляється у професії, яка чинить безпосередній вплив на його життєдіяльність.

Професійний та особистісний розвиток може або взаємно підпорядковуватися один одному, або взаємно посилювати один одного. Щоб досягти певного способу життя, матеріального добробуту, людина може використовувати професію, підпорядкувати її своїй особистості. Слід зазначити, що успішний процес фахового зростання можливий тільки за умови розвитку особистості, яка здатна 
розпізнати стан своїх властивостей, досягти усвідомлення необхідності змін і перетворень свого внутрішнього світу, нових можливостей самореалізації у праці.

Відповідальність в трудовій діяльності пов'язана з виконанням рольових обов'язків фахівця, які становлять нормативний контекст. Саме на основі них оцінюється реальна відповідальність. Кожний член виробничого колективу виконує безліч різноманітних обов'язків. Одні з них, як правило, жорстко задані, інші встановлені не так чітко. Здійснення низки обов'язків контролюється систематично, і за їхнє невиконання до працівників застосовуються певні санкції. Інші ж обов'язки контролюються не настільки суворо, і за їхнє невиконання працівник формально не карається. Ефективність реалізації будь-яких рольових обов'язків залежить не тільки від зовнішнього контролю й суворості використовуваних санкцій, але й від того, якою мірою сам працівник визначає коло своїх обов'язків і бере на себе відповідальність за їхнє виконання. Ступінь здійснення працівником рольових вимог залежить від того, як вони реалізуються іншими членами цього колективу. Одні вимоги (норма виробітку), втілюються в життя всіма працівниками у більшій мірі, інші (дотримання правил техніки безпеки або економія матеріалів), потребують менше уваги. Чіткість виконання рольових обов'язків залежить також від того, чи вважає працівник дані обов'язки безпосередніми або «дискреційними» (виконуються на власний розсуд працівника, добровільно й не контролюються так суворо, як безпосередні) [21, с. 397].

Особистість, утверджуючи себе над професією, сама стає головною цінністю, тобто цінує себе, а не професію. У випадку домінування професії як найважливішої цінності, в ім'я якої розгортається і утверджується особистість у професії, відбувається «доростання» особистості до професіонала. Найсприятливішими для обох процесів $є$ відповідність професійного й особистісного розвитку, коли досягнення професійних вершин є водночас і вершиною розвитку особистості [12, с. 366].

Отож, професійна відповідальність як один 3 найбільш значущих аспектів соціальної, $\epsilon$ структурним компонентом будь-якої професійної діяльності, яка успішно розвивається. Це комплекс особистісних якостей фахівця, що забезпечує усвідомлення і переживання ним особистісної відповідальності за виконання та результати своєї професійної діяльності, відповідність вимогам соціально та професійно схвалюваної поведінки [20, с. 23].

Л. Бешевець та О. Мухаметшин визначають професійну відповідальність як інтеграційну особисту якість спеціаліста, яка має своє відображення в морально-правовому ставленні спеціаліста до своїх професійних обов'язків та вимагає обов'язкового виконання норм, правил, вимог; при цьому спеціаліст самостійно обирає та критично оцінює власні дії, передбачає їх наслідки [2; 22].

Інші науковці професійну відповідальність людини трактуюють не як «одноразові» почуття, мотивовані цінністю або значимістю її діяльності, не як наслідок контролю, що здійснюється ззовні (державного, адміністративного та ін.), а як якість особистості, що сформувалася на особистісній основі, мотивована потребою вдосконалювати результати своєї професійної діяльності 3 метою самоактуалізації $[15$, с. 125$]$.

Профресійну відповідальність визначають ще й фахова компетентність, досвід, ціннісне сприйняття суб'єктом своєї професії та усвідомлення її суспільної значущості. Важливим для професійної компетентності сферою особистості, роль якої явно недооцінювалася донедавна в психологічних дослідженнях, є самосвідомість особистості, оцінка людиною своїх знань, поведінки, морального вигляду, інтересів, ідеалів, мотивів поведінки, почуттів і думок .

В.Н. Козієв визначає професійну самосвідомість як складний особистісний механізм, що відіграє активну роль у професійній діяльності, за допомогою якого можливий активний саморозвиток, свідоме формування в собі професійно значущих якостей особистості, професійної компетентності та майстерності [11].

С. Букша зазначає, що професійна відповідальність інтегрує морально-вольові та професійні якості майбутніх вчителів у новоутворення, яке цілеспрямовано формується і розвивається в умовах спеціальної підготовки [6].

Найважливішим структурним компонентом самосвідомості особистості $є$ самооцінка, сутність якої полягає в усвідомленні себе та у певному ставленні до самого себе. Самооцінка - одна з найбільш вивчених сторін самосвідомості. Самооцінку можна розглядати як «ядро» самосвідомості, фундаментальну властивість особистості, яка відіграє провідну роль у структурі їі мотиваційної сфери, у регуляції людиною своєї поведінки та діяльності, у формуванні таких якостей особистості, як 
самокритичність, упевненість в собі, у рівні домагань. Формування адекватної самооцінки $є$ важливим етапом розвитку професійної компетентності майбутнього фахівця.

Чинником, що визначає ефективність фрормування профресійної компетентності майбутніх фахівців, є рівень самооцінки. Самооцінка є центральним компонентом особистості, суттєво впливає на ставлення людини до себе та інших і виступає одним із важливих регуляторів ії̈ поведінки. Самооцінка вказує на рівень психологічного розвитку фахівців та адекватного визначення ними своїх особистісних якостей і тісно пов'язана з самоефективністю - вмінням студента усвідомлювати власні здібності для фрормування такої поведінки, яка відповідає певній задачі або ситуації [8].

А отже, фрормування профресійної відповідальності - це процес, у результаті якого складається цілісний образ себе як профресіонала, що включає комплекс уявлень про себе як про професіонала, систему відносин взаємної відповідальності і установок до себе як до професіонала $[4 ; 9 ; 10]$.

\section{III Результати}

Досліджено, що професійна відповідальність є результатом відображення об'єктивно необхідних взаємин у колективі, які характеризуються усвідомленою особистістю необхідністю виконувати професійні вимоги; моральний і професійний обов'язок; соціальні норми та відповідати за свої професійні дії перед собою, колегами, колективом і суспільством [13;18; 23].

Аналіз наукових джерел дає підстави виділити умови формування професійної відповідальності, сукупність обставин, факторів, вимог, впливів, які позитивно позначаються на освітньому процесі. Встановлено, що визначення педагогічних умов, які істотно впливають на формування професійної відповідальності, ґрунтується на фракторах, професійних інтересах, моральних цінностях, що безпосередньо впливають на формування професійно значущих якостей майбутніх фахівців.

До першої групи відносять методи переконання і навіювання, що створюють моральну установку, яка скерована на свідомість людини. Друга група - це тренінги, проекти та вправи, які використовують для закріплення відповідальної поведінки на практиці. Третя - методи, спрямовані на вольові якості особистості, що реалізується за допомогою схвалення, вимог та контролю. До четвертої групи відносять прийоми виховної роботи, а саме: самопізнання, самооцінку та саморозвиток [6].

Л.В. Бешевець стверджує, що процес формування професійної відповідальності можливий за умови гуманізації процесу співпраці майбутнього спеціаліста та викладача (процес активної взаємодії, взаємоповаги дає можливість студентові розвиватись та стати професіоналом; переживання позитивних емоцій та бачення себе учасником педагогічного процесу сприятливо впливає на розвиток професійної відповідальності); у період вивчення педагогічних дисциплін, проходження педагогічної практики (під час самостійної роботи доречним $є$ використання задачного підходу, принципу рольової перспективи (педагогічні задачі, ігри, рольові ситуації, творчі завдання), диференціації та індивідуалізації навчання. Використання цих прийомів має на меті розвиток мотивації, критичного та педагогічного мислення та закріплення наявних умінь; моделювання професійних ситуацій (мета вдосконалити вміння, викликати зацікавленість майбутньою професією); спрямування усіх виховних дій на розвиток регуляторної основи діяльності майбутніх фрахівців. Регуляторна основа формує поняттєвий апарат мислення педагога - принципи та критерії оцінки практичної діяльності. При прийнятті рішення педагог орієнтується на власний поняттєвий апарат. Тому, на думку вченої, навчальний процес повинен бути організований таким чином, щоб студенти розуміли зміст, структуру, критерії професійної відповідальності та розуміли важливість ї̈ значення; закріплення самоаналізу та самооцінки отриманих результатів під час власної навчальної діяльності, сформованості рівня професійних якостей, що відображає професійну відповідальність [2].

Е.К. Гардонова виділяє когнітивний, мотиваційний та діяльнісний показники професійної відповідальності. Ю.М. Ладнова - мотиваційний, когнітивний, комунікативний, емоційно-вольовий, практичний, рефрлексивний, стійкість особистості, емпатія, мобільність поведінки, інтелектуальна гнучкість [7].

Необхідними складовими механізму формування професійної відповідальності особистості фахівців виступають: а) індивідуально-психологічні особливості особистості професіонала; б) цінності особистості як прихований регулятор поведінки; в) інваріантна стійка професійна позиція фахівця та модель профеесійної діяльності; г) володіння алгоритмом прийняття рішень; д) мотиваційна, ціннісна, 
емоційна саморегуляція та рефлексія [16, с. 323]. При цьому особливу увагу варто зосередити на формуванні позитивної мотивації майбутніх фахівців до навчання. Інтерес до мотивації навчання передбачає суттєве збільшення частки самостійної роботи і орієнтований на «зрілу», відповідальну особистість, яка здатна проявляти активність, вільно орієнтуватися в ситуації, постійно самовдосконалюватися, приймати самостійні рішення. Тому психолого-педагогічна структура профресійної відповідальності майбутнього фрахівця включає синтез практичного, інтелектуального, вольового й емоційного компонентів.

Виокремлено основні елементи, що визначають рівень розвитку професійної відповідальності. До них відносимо: усвідомлення людиною норм, правил, моделей своєї професії як еталонів для усвідомлення своїх якостей; усвідомлення цих якостей в інших людей; самооцінювання людиною своїх окремих сторін з опорою на ретроспективну, актуальну і потенційну, ідеальну професійну самооцінку; відповідальне ставлення до себе в цілому [4; 9; 10].

\section{IV Обговорення}

На основі аналізу літературних джерел з означеної проблеми встановлено, що для формування професійної відповідальності особистості фахівця обов'язково варто акцентувати увагу на його професійно значущі якості, які потрібні в діяльності певної професії; впливають на успішність навчальної діяльності; дають можливість повністю реалізувати особистісний потенціал, розвиток яких забезпечує надалі високу якість професійної діяльності. А отже, у процесі спеціальної підготовки формуються професійно важливі якості фахівця, що визначають його придатність, компетентність і готовність до виконання профресійного обов'язку.

Формування відповідальності майбутніх фахівців, яка забезпечує їхній особистісний розвиток та самореалізацію як суб'єкта майбутньої професійної діяльності, має стати професійною якістю кожного випускника. Вона залежить від ефективно створених умов, формування позитивної мотивації студентів до навчання, пошуку нових організаційних форм і методів навчання, спрямованих на виховання компетентної особистості фахівця, прагнення до прийняття самостійних рішень та формування професійної готовності у майбутній діяльності [19].

Доведено, що формування професійної відповідальності майбутнього фрахівця стає можливим завдяки поетапності й керованості підготовки, забезпечення інтегративних зв'язків особистісних, педагогічних та фахових складових змісту підготовки; розробці змістово-організаційних засад на основі взаємозв'язку теорії і практики; залучання студентів до різноманітних видів діяльності.

Формування професійної відповідальності майбутніх фахівців є складним і динамічним процесом, який має здійснюватися у взаємодії особистості (суб'єктивного прийняття відповідальності) і професії (об'єктивних професійних вимог). Звідси, у структурі профресійної моделі майбутнього фрахівця відповідальність виступає найбільш значущою базовою якістю, яка проявляється в особистісному (відповідальне ставлення до професійної справи та до себе), функціональному (прояв в різних напрямках діяльності майбутнього фрахівця) та предметно-орієнтувальному (особистісно-професійне зростання та показник готовності до професійної діяльності).

Процес формування професійної відповідальності майбутніх фахівців буде ефективним, якщо детермінувати якісні зрушення в мотивації відповідальної поведінки студентів, в усвідомленні ними відповідальності перед сукупністю інстанцій, та здійснювати підготовку майбутніх фахівців на основі системного забезпечення педагогічних умов формування професійної відповідальності студентів, яка передбачає застосування наступних педагогічних впливів (формування мотивації відповідальності в студентів; всебічне розширення самостійності студентів у різних видах діяльності; індивідуальний підхід до кожного з них з урахуванням рівня сформованості відповідальності; раціональне використання провідних видів проектованої майбутньої діяльності на заняттях з аналізу професійно-відповідальних ситуацій, зважаючи на обумовленість соціально-психологічного розвитку особистості об'єктивними та суб'єктивними умовами віку) [18; 23, с. 278-283].

Запорукою ефективності розвитку професійної відповідальності майбутніх фахівців $є$ інтеграція різних засобів, форм і методів, які сприятимуть моделюванню власної відповідальної поведінки, критичному розгляду стратегії та варіантів взаємин в соціальному середовищі, формуванню вмінь приймати відповідальні й усвідомлені рішення; розвиватимуть прагнення до активної участі в 
суспільному житті, усвідомлення меж особистої і колективної відповідальності, прагнення до самоосвіти та самовдосконалення. Саме таким чином відповідальність «дозволяє гармонізувати розвиток загальних і професійних якостей у системну цілісність, що, в свою чергу, утверджує їхню здатність до прогнозування наслідків власної науково-пізнавальної та різнобічної громадсько-корисної діяльності» [3].

\section{V Висновки}

Зважаючи на результати вивчення наукових джерел, аналізу та узагальнення викладених у них ідей, визначено, що відповідальність $€$ надзвичайно складним морально-етичним, психічним утворенням та суперечливим явищем. Відповідальність носить індивідуальний і водночас суспільний характер та відіграє важливу роль у забезпеченні нормальної життєдіяльності суспільства і людини у ньому, в реалізації своєї місії й особистісного потенціалу. Передумовою відповідальності завжди є вибір людиною можливої поведінки, що проявляється у власній активності, діяльності та самовдосконаленні.

Особливе місце у складній системі особистої відповідальності посідає професійна відповідальність, яка $\epsilon$ інтегративною складовою професійної готовності майбутніх фахівців. Становлення майбутнього фахівця передбачає розвиток його як особистості, який відбувається в діяльності, тому особистість головним чином проявляється у професії, яка чинить безпосередній вплив на його життєдіяльність. Основою розвитку значимих мотивів професійної діяльності $€$ виховання суспільних інтересів і глибоке усвідомлення їх важливості.

Профресійний та особистісний розвиток може або взаємно підпорядковуватися один одному, або взаємно посилювати один одного. Професійна відповідальність є результатом відображення об'єктивно необхідних взаємин у колективі, які характеризуються усвідомленою особистістю необхідністю виконувати професійні вимоги; моральний і професійний обов'язок; соціальні норми та відповідати за свої професійні дії перед собою, колегами, колективом і суспільством.

Необхідними складовими механізму формування професійної відповідальності особистості фахівців є індивідуально-психологічні особливості особистості профресіонала; цінності особистості як регулятор поведінки; інваріантна стійка професійна позиція фахівця; володіння алгоритмом прийняття рішень; мотиваційна, ціннісна, емоційна саморегуляція та рефлексія.

Доведено, що формування професійної відповідальності майбутнього фрахівця стає можливим завдяки поетапності й керованості підготовки, забезпечення інтегративних зв'язків особистісних, педагогічних та фрахових складових змісту підготовки; розробці змістово-організаційних засад на основі взаємозв'язку теорії і практики; залучання студентів до різноманітних видів діяльності.

Головними умовами формування професійної відповідальності майбутніх спеціалістів $€$ формування мотивації відповідальної поведінки, професійна спрямованість, педагогічна майстерність викладачів, ефективна практична підготовка майбутніх спеціалістів.

Результативність виховання професійної відповідальності залежить від особистих і суспільних мотивів та співвіднесення особистих та суспільних інтересів, оскільки в мотивах відбувається своєрідне інтегрування зовнішніх впливів (обов'язків) і внутрішніх спонукань (потреби в професійній діяльності). Зовнішні впливи, проходячи через призму свідомості особистості, виявляються в мотивах їх діяльності.

\section{Бібліографічні посилання}

1. Закон України «Про Стратегію сталого розвитку України до 2030 року від 07 серпня 2018 року. № 9015. URL: http://search.ligazakon.ua/l doc2.nsf/link1/JH6YF00A. (дата звернення 08.08.2020).

2. Бешевец Л. В. Формирование профессиональной ответственности будущих педагогов в условиях педвуза : дисс.... канд. пед. наук : 13.00.01 / Криворожский гос. педагогический ин-т. Кривой Рог, 1997. 184 с.

3. Бех І. Д. Від волі до особистості. К. : «Україна-Віта». 1995. 220 с.

4. Борисова Е. М., Логинова Г. П. Индивидуальность и профессия : учеб. пособие. М. : Знание, 1991. 80 с.

5. Бродовська В.Й., Патрик I П., Яблонко В.Я. Тлумачний словник психологічних термінів. Київ: Професіонал, 2005. 224 с.

6. Букша С. Б. Формирование профессиональной ответственности будущих специалистов. Педагогuка. 2015. URL: http://www.rusnauka.com/9_SNP_2015/Pedagogica/2_189. (дата звернення 06.08.2020).

7. Гарданова Е. К. Развитие профессиональной ответственности будущего специалиста. Психология и педагогика: методика и проблемы практического применения: научный журнал. Чебоксары, 2013. С. 43. 
8. Гончарова-Горянська М. Соціальна компетентність : поняття, зміст, шляхи формування в дослідженнях зарубіжних авторів. Рідна школа. 2004. № 7-8.

9. Йонас Г. Принцип відповідальності. У пошуках етики для технологічної цивілізації : монографрія. К. : Лібра, 2001.400 с.

10. Каганов А. Б. Рождение специалиста : профессиональное становление студента : учеб. пособие. Минск : Изд-во БГУ, 1983. $111 \mathrm{C}$.

11. Козієв В. М. Психологічний аналіз професіонального самопізнання вчителя : дис. ... канд. психол. наук : 19.00 .07 / Луцький педагогічний інститут. Луцьк, 1980. 194 с.

12. Копиць Л. В. Психологія особистості : навч. посіб. К. : Києво-Могилянська академія, 2007. 460 с.

13. Макаревич О. П. Мотиваційне підґрунтя регуляції власної поведінки особистості: навч.-метод. посіб. К. : ВГІ НАОУ, $2000.96 \mathrm{c}$.

14. Мануйлов Є. М. Філософський аналіз проблеми професійної відповідальності. Вісник Національної юридичної академії імені Ярослава Мудрого. Сер. : Філософія, фрілософія права, політологія, соціологія : зб. наук. пр. / Національна юридична академія України ім. Я. Мудрого. Х. : Право, 2011. № 8. С. 11-19.

15. Міщеня О., Третяк О. Сутність професійно-педагогічної відповідальності майбутнього вчителя початкової школи. Нова педагогічна думка. 2019. № 3 (99). С. 122-127.

16. Миленкова Р. В. Механізми формування професійної відповідальності в процесі фрахової підготовки студентів. Педагогічні науки : теорія, історія, інновації, технології : науковий журнал. Суми : СумДПУ ім. А.С. Макаренка, 2010. № 4. C. 321-329.

17. Муздыбаев К. Психология ответственности. Л. : Наука, 1983. 240 с.

18. Плахотный А. Ф. Проблемы социальной ответственности: навч. посіб.ник. Харьков : ХГУ, 1981. 232 с.

19. Потапюк Л. М. Соціально-психологічні особливості формування відповідальності студентської молоді. Ольвійський форум - 2020 : стратегії країн Причорноморського регіону в геополітичному просторі : XIV Міжнар. наук. конф. м. Миколаїв : програма та тези : II Міжнар. наук.-практ. конф. 4 червня 2020 р., «Залучення патріотично активної молоді до розвитку громадянського суспільства як чинник соціальної безпеки України» / Чорном. нац. ун-т ім. Петра Могили. Миколаїв : Вид-во ЧНУ ім. Петра Могили, 2020. С. 120-122.

20. Савчин М.В.Психологія відповідальної поведінки : монографія. Івано-Франківськ : Місто НВ, 2008. 280 с.

21. Ткачов А. В. Проблема професійної відповідальності особистості в психології. Проблеми екстремальної та кризової психології. 2010. Вип. 8. С. 394-400.

22. Торшевська О. В. Психолого-педагогічні аспекти формування професійної відповідальності вчителів початкових класів в умовах педагогічного коледжу. Вісник Луганського національного університету ім. Тараса Шевченка. URL: http://www.stattionline.org.ua/pedagog/104/17998-psixologo-pedagogichni-aspekti-formuvannya-profesijno\%D1\%97vidpovidalnosti-vchiteliv-pochatkovix-klasiv-v-umovax-pedagogichnogo-koledzhu.html. (дата звернення 04.08.2020).

23. Шусть В. В. Професійна відповідальність як особистісна риса майбутніх фахівців-аграрників. Науковий вісник Національного аграрного університету. 2005. № 8. С. 278-283.

\section{References}

1. On the Strategy of Sustainable Development of Ukraine until 2030. Law of Ukraine dated 07/08/2018 No. 9015. URL: http://search.ligazakon.ua/l doc2.nsf/link1/JH6YF00A. (acceded 08.08.2020). (in Ukrainian)

2. Beshevec, L. V. (1997). Formation of professional responsibility of future teachers in the conditions of pedagogical high school [Formirovanie professionalnoj otvetstvennosti budushih pedagogov $\mathrm{v}$ usloviyah pedvuza]. Pedagogic science candidate theses, 13.00.01, Kryvyi Rih State Pedagogical Institute, Krivoy Rog, 184. [in Russian]

3. Bekh, I. D. (1995). Vid voli do osobystosti. Kyiv, Ukraine-Vita, 220 p. [in Ukrainian]

4. Borisova, E. M., Loginova, G. P. (1991). Individualnost i professiya, Moscow, Knowledge, 80 p. [in Russian]

5. Brodovska, V. I., Patryk, I.P., Yablonko, V.la. (2005). Tlumachnyi slovnyk psykholohichnykh terminiv. Kyiv: Professional, 224 p. [in Ukrainian]

6. Buksha, S. B. (2015). Formation of professional responsibility of future specialists [Formirovanie professionalnoj otvetstvennosti budushih specialistov]. Pedagogy [Pedagogika]. URL: http://www.rusnauka.com/9_SNP_2015/ Pedagogica/2_189. (acceded 06.08.2020). [in Russian]

7. Gardanova, E. K. (2013). Development of professional responsibility of the future specialist [Razvitie professionalnoj otvetstvennosti budushego specialista]. Psychology and pedagogy: methods and problems of practical application: a scientific journal [Psihologiya i pedagogika : metodika i problemy prakticheskogo primeneniya: nauchnyj zhurnal, 43. [in Russian]

8. Honcharova-Horianska, M. (2004). Social competence: concept, content, ways of formation in researches of foreign authors [Sotsialna kompetentnist : poniattia, zmist, shliakhy formuvannia v doslidzhenniakh zarubizhnykh avtoriv]. Native school [Ridna shkola], 7-8. [in Ukrainian]

9. Yonas, H. (2001). The principle of responsibility. In search of ethics for technological civilization [Pryntsyp vidpovidalnosti. $U$ poshukakh etyky dlia tekhnolohichnoi tsyvilizatsii]. Kyiv : Libra, 400. [in Ukrainian]

10. Kahanov, A. B. (1983). Birth of a specialist: professional development of a student [Rozhdenye spetsyalysta : professyonalnoe stanovlenye studenta]. Minsk: BSU Publishing House,111. [in Russian]

11. Koziiev, V. M. (1980). Psychological analysis of professional self-knowledge of a teacher [Psykholohichnyi analiz profesionalnoho samopiznannia vchytelia]. Psychological science candidate theses, 19.00.07, Lutsk Pedagogical Institute, Lutsk, 194. [in Ukrainian] 
12. Kopyts, L. V. (2007). Personality psychology [Psykholohiia osobystosti]. Kyiv : Kyievo-Mohylianska akademiia, 460. [in Ukrainian]

13. Makarevych, O. P. (2000). Motivational basis for the regulation of one's own behavior [Motyvatsiine pidgruntia rehuliatsii vlasnoi povedinky osobystosti]. Kyiv : VHI NAOU, 96. [in Ukrainian]

14. Manuilov, Ye. M. (2011). Philosophical analysis of the problem of professional responsibility [Filosofskyi analiz problemy profesiinoi vidpovidalnosti]. Bulletin of the Yaroslav the Wise National Law Academy. Ser. : Philosophy, philosophy of law, political science, sociology: collection of scientific works. [Visnyk Natsionalnoi yurydychnoi akademii imeni Yaroslava Mudroho. Ser. : Filosofiia, filosofiia prava, politolohiia, sotsiolohiia : zb. nauk. pr.], 8, 11-19. [in Ukrainian]

15. Mishchenia, O., Tretiak, O. (2019). The essence of professional and pedagogical responsibility of the future primary school teacher [Sutnist profesiino-pedahohichnoi vidpovidalnosti maibutnoho vchytelia pochatkovoi shkoly]. New pedagogical thought [Nova pedahohichna dumka], 3 (99), 122-127. [in Ukrainian]

16. Mylenkova, R. V. (2010). Mechanisms of formation of professional responsibility in the process of professional training of students [Mekhanizmy formuvannia profesiinoi vidpovidalnosti v protsesi fakhovoi pidhotovky studentiv]. Pedagogical sciences: theory, history, innovations, technologies: scientific journal [Pedahohichni nauky : teoriia, istoriia, innovatsii, tekhnolohii : naukovyi zhurnal], 4, 321-329. [in Ukrainian]

17. Muzdybaev, K. (1983). Psychology of responsibility [Psihologiya otvetstvennosti]. Lvov : Nauka, 240. [in Russian]

18. Plahotnyj, A. F. (1981). Problems of social responsibility [Problemy socialnoj otvetstvennosti]. Harkov : HGU, 232. [in Russian]

19. Potapiuk, L. M. (2020). Socio-psychological features of the formation of responsibility of student youth [Sotsialnopsykholohichni osoblyvosti formuvannia vidpovidalnosti studentskoi molodi]. Olbia Forum - 2020: strategies of the Black Sea region in the geopolitical space [Olviiskyi forum - 2020 : stratehii krain Prychornomorskoho rehionu $v$ heopolitychnomu prostori], 120-122. [in Ukrainian]

20. Savchyn, M. V. (2008). Psychology of responsible behavior [Psykholohiia vidpovidalnoi povedinky]. Ivano-Frankivsk : Misto $\mathrm{NV}, 280$. [in Ukrainian]

21. Tkachov, A. V. (2010). The problem of professional responsibility of the individual in psychology [Problema profesiinoi vidpovidalnosti osobystosti v psykholohii]. Problems of extreme and crisis psychology [Problemy ekstremalnoi ta kryzovoi psykholohii], 8, 394-400. [in Ukrainian]

22. Torshevska, O. V. Psychological and pedagogical aspects of the formation of professional responsibility of primary school teachers in a pedagogical college [Psykholoho-pedahohichni aspekty formuvannia profesiinoi vidpovidalnosti vchyteliv pochatkovykh klasiv $v$ umovakh pedahohichnoho koledzhu]. Bulletin of Luhansk National University. Taras Shevchenko [Visnyk Luhanskoho natsionalnoho universytetu im. Tarasa Shevchenka]. URL: http://www.stattionline.org.ua/pedagog/104/17998-psixologo-pedagogichni-aspekti-formuvannya-profesiino\%D1\%97vidpovidalnosti-vchiteliv-pochatkovix-klasiv-v-umovax-pedagogichnogo-koledzhu.html. (acceded 04.08.2020). [in Ukrainian]

23. Shust, V. V. (2005). Professional responsibility as a personal trait of future agricultural specialists. [Profesiina vidpovidalnist yak osobystisna rysa maibutnikh fakhivtsiv-ahrarnykiv]. Scientific Bulletin of the National Agrarian University [Naukovyi visnyk Natsionalnoho ahrarnoho universytetu], 8, 278-283. [in Ukrainian]

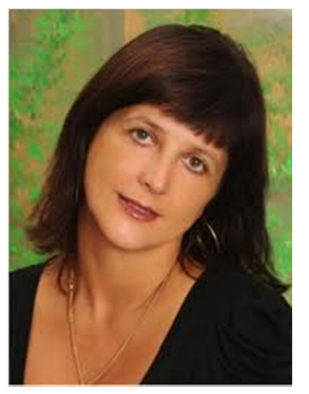

Потапюк Лілія Миколаївна,

к.пед.н., доцент, доцент кафедри професійної освіти та комп'ютерних технологій,

Луцький національний технічний університет,

вул. Львівська, 75, м. Луцьк, Волинської обл., Україна, 43018.

Тел. +38(050) 17-27-719. E-mail: potapiuk_@bigmir.net

Potapiuk Liliia Mykolaivna,

Ph.D. in Pedagogics, Associate Professor,

Associate Professor of the Vocational Education and Computer Technologies Department.

Lutsk National Technical University, 75, Lvivska str., Lutsk, Volyn Region, Ukraine, 43018.

Tel. +38(050) 17-27-719. E-mail: potapiuk I@bigmir.net

ORCID: 0000000308308758

Citation (APA):

Potapiuk, L. (2020). Development of the prospective specialists' professional responsibility. Engineering and Educational

Technologies, 8 (3), 33-43. doi: https://doi.org/10.30929/2307-9770.2020.08.03.03

\section{Цитування (ДСТУ 8302:2015):}

Потапюк Л. М. Формування професійної відповідальності майбутніх фрахівців / Інженерні та освітні технології. 2020. Т. 8. № 3. C. 33-43. doi: https://doi.org/10.30929/2307-9770.2020.08.03.03

обсяг статmi: $\quad$ сторінок-11; умовних друк. аркушів - 1,593. 